Short Communication

\title{
Role of rGO on Structural, Optical, and Photocatalytic Properties of $\mathrm{Cu}_{2} \mathrm{O} / \mathrm{rGO}$
}

\author{
AiJiao Xu ${ }^{1}$, Bo Li $i^{2}$, BaiShao Zhan ${ }^{1}$, ShuangXi Xue ${ }^{1}$, RenQing Guo ${ }^{1}$, WenWu Zhong ${ }^{1 *}$ \\ ${ }^{1}$ Department of Materials, Taizhou University, Taizhou 318000, China \\ ${ }^{2}$ Second Hospital of Jilin University, Changchun, China \\ *E-mail: tianmenwenwu@163.com
}

doi: $10.20964 / 2017.01 .05$

Received: 8 September 2016 / Accepted: 12 October 2016 / Published: 12 December 2016

\begin{abstract}
The composite photocatalysts composed of $\mathrm{Cu}_{2} \mathrm{O}$ and reduced graphene oxide (rGO) were prepared using a simple chemical method. The SEM, XRD and Raman spectrum indicate that graphene is well loaded to the surface of $\mathrm{Cu}_{2} \mathrm{O}$. The UV-vis DRS spectra results reveal that the $\mathrm{Cu}_{2} \mathrm{O}$ had absorbed more visible light by recombination with graphene. The PL intensity of pure $\mathrm{Cu}_{2} \mathrm{O}$ is decreased by the loading with rGO. The BET of pure $\mathrm{Cu}_{2} \mathrm{O}$ is enhanced 3.6 times via the loading with $\mathrm{rGO}$. The obtained $\mathrm{Cu}_{2} \mathrm{O} / \mathrm{rGO}$ composites exhibit higher photocatalytic activity that is 4.32 times larger than that of $\mathrm{Cu}_{2} \mathrm{O}$. The enhanced photocatalytic property of the $\mathrm{rGO} / \mathrm{Cu}_{2} \mathrm{O}$ composites is ascribed to the increasing of charge transfer and specific surface area.
\end{abstract}

Keywords: Photocatalyst, Cuprous oxide, Graphene, Visible light

\section{$\underline{\text { FULL TEXT }}$}

(C) 2017 The Authors. Published by ESG (www.electrochemsci.org). This article is an open access article distributed under the terms and conditions of the Creative Commons Attribution license (http://creativecommons.org/licenses/by/4.0/). 